\title{
Social Practice of Early Marriage
}

\author{
Yulkardi $^{1}$ \\ \{yulkardi@gmail.com \}
}

Faculty of Social and Political Science, Universitas Andalas, Padang, Indonesia

\begin{abstract}
The National Population and Family Planning Agency (BKKBN) has stated that the birth rate among young women is still high at around 48 per 1,000 women aged 15-19 (IDHS 2012). "This achievement is still far from the 2015 MDG target (at that time), which is, around 30 per 1,000 young women of the same age," said the Deputy of Family Welfare and Family Development (KSPK). According to the analysis of child age marriage data, specifically in West Sumatra in 2012, the percentage of women ever married aged 20-24 years who were married before the age of 16 was $2.1 \%$ or equal to 4,470 children from 212,900 children in the same year (BPS and Unicef 2015 (p.58). The theme of child marriage is not something new discussed, as well as the risks that follow it. This phenomenon is still considered interesting, studied starting from the dynamics of demographic behavior such as the trend of changing goals of sexual activities that experience the transition from creation to recreational activities (Afrizal, on the talk show Musda XI PKBI West Sumatra, May 1, 2015). Until the population sociology study was interested in seeing the connection between sexual relations with systems and social structures, sexual relations with patterns of social interaction, sexual relations with norms and values and sexual relations in the context of institutions and institutions in society, and sexual relations related to various elements - elements of socio-cultural change. These aspects can be observed variables to understand the phenomenon of child marriage. How to understand the motives of social practices for child marriage. Giddens' structuration theory perspective suggests seeing the actions of agents (agents) with structures that are duality. For the structure actor as the basis (source) of action, and influential in three ways. First: discourse, symbol symbols in the community and their meaning influence the 'ongoing' marriage of children. The 'sell' symbol for girls can be implicitly 'exploited' by male adolescents to have a 'mutually mutually' reason at any time. Second: the mastery of external individuals who play a role in the phenomenon of early marriage. Two resources are forming the structure of external mastery of individuals who are distorted. (1). Mastery of allocative for goods/material/ economy. Manipulation of marriage permit letters via 'bribe' (age issue). Effect of smartphones, internet; exacerbated by the situation of parents and their work, related to the allocation of time for 'education' in the family for children. (2). Authoritative mastery of people / actors / politicians. Like, promiscuity; the child is no longer "as ordered" by the parents, negotiating the arrangement of the marriage certificate, because of the influence of the character. Third: the structure of normative legitimacy (formal and non-formal) also influences the phenomenon of child marriage.
\end{abstract}

Keywords: Social Practice; Child Age Marriage.

\section{Introduction}

Both academics, activists and the government do not support child marriages, often referred to as early marriage or young marriage, and even try to eliminate them. The Indonesian 
government has issued a law banning child marriages, which is defined as marriage under the age of 16 for women and 19 years for men. Called child marriage because children are usually defined as people under the age of 18 (Law No.23 of 2002 concerning Child Protection - article 1 paragraph 1). However, child marriage is still practiced in various regions in Indonesia, including in several nagari / villages in West Sumatra (Puspitasari, 2006; Yopi, 2012; Zulkifli, 2012; Sisrinawati, 2014). Even in certain nagari / villages the practice of child marriage is still seen as a matter of course, nagari / desa is called a pouch of child marriage.

Child marriage, in this study, was defined as a marriage that occurred between a 19-yearold man and a 16-year-old woman (in accordance with Marriage Law No.1 1974, article 7 paragraph 1), besides having a negative impact on the perpetrator, impact on society and the country. Child marriages that occur a lot cause social and economic burdens for the community and the country due to their contribution to maternal and infant mortality and domestic violence. As far as the population control is concerned, child marriages contribute to high population growth associated with opportunities for large women to give birth to many children. Therefore, this phenomenon needs to be studied because there is a lack of knowledge about it, starting from the dynamics of demographic behavior such as the trend of changing the purpose of sexual activity from procreation to recreation. Sociological studies that look at the links between sexuality and the system and social structure and the prevailing patterns of social interaction, with the continued practice of child marriage need to be done to enable finding effective treatment alternatives.

\section{Method}

The research objective is achieved by conducting qualitative research in a nagari in

The South Coastal District where many early marriages of the past three years (2011-2014) occurred. In-depth interviews and FGDs collected data. Quantitative data to support findings were collected from local health centers. The use of methods and qualitative data analysis refers to Miles and Huberman (1999) and Afrizal (2014).

\section{Findings}

\subsection{Social Reproduction of Child Age Marriage}

The practice of child marriage in the nagari studied is an intergenerational phenomenon, there is a reproduction of child marriage by a new generation or generation of children. The indication is that all the parents of the daughters who carried out the marriages of the children under study (15 cases) also had marriages at the age of their children, namely, between the ages of 14-16 years for mothers, and between 16-22 years for fathers.

The average age at first marriage for women in West Sumatra is 22.1 years. The South Coastal District is one of the highest contributors to the first marriage below the West Sumatra average, which is an average of 20.6 years. There were found pockets of child marriage in Pesisir Selatan District, one of which was Nagari Koto Nan Tigo Utara Surantih, Sutera District. From 2011 to 2014 there were 18 child marriages, 25\% of PUS aged between 15-19 years at that time. There are 72 couples of childbearing age (PUS) aged between 15-19 years in this region at the 
same period. That number actually shows the magnitude of the incidence of marriage at the age of children (early) in Nagari, with the reason that they have already used contraception (CU).

Table 1. Number of Fertile Age Couples (PUS) and Child Age Marriage (PUA) in 2011-2014,in Kanagarian Koto Nan Tigo Utara Surantih, Kec. Sutera, Kab. Pessel.

\begin{tabular}{lllllll}
\hline No & \multicolumn{1}{c}{ Village } & $\begin{array}{c}\text { Total PUS } \\
(15-19)\end{array}$ & $\begin{array}{c}\text { Total PUA } \\
+(\geq 13- \\
\leq 14)\end{array}$ & $\begin{array}{c}\text { Total PUA } \\
+(\geq 14- \\
\leq 15)\end{array}$ & $\begin{array}{c}\text { Total PUA } \\
+(\geq 15-\leq 16)\end{array}$ & $\begin{array}{c}\text { Total } \\
\text { PUA }\end{array}$ \\
\hline 1. & $\begin{array}{l}\text { Kayu Gadang } \\
\text { Tangah }\end{array}$ & 26 & - & 3 & 5 & 8 \\
2. & $\begin{array}{l}\text { Kayu Gadang } \\
\text { 3II Koto Kayu }\end{array}$ & 28 & - & 3 & 4 & 7 \\
$\quad \begin{array}{l}\text { Gadang } \\
\text { J U M L A H }\end{array}$ & 72 & - & - & 3 & 3 \\
\hline
\end{tabular}

Source: Puskesmas Kecamatan Sutera \& Data Primer PUA, Nagari Koto Nan Tigo Utara Surantih, Kec. Sutera, Kab. Pesisir Selatan-Sumbar (2011-2014) .

Economic reasons are not an important cause of child marriage at this time in the research location. As the Unicef report (2005) mention that one of the factors causing child marriage is as a way to survive economically. The report states that poverty is the main factor that causes early marriage. A deep poverty situation, the position of girls becomes a family economic burden, then marrying them is seen as a way out. The reason is that parents assume that their lives have been "borne" by their husbands. Community leaders say that in the past Surantiah people married young for economic reasons. They said at that time, only by immediately marrying off their daughters, parents could ease the economic burden that must be borne. At that time, couples married early in the past, more independent and mature, male adolescents since childhood have been involved with their parents' work in gambier fields. These economic reasons are no longer an important cause of child marriages at the research site (at the time of this study). All cases of married women at the age of the child being studied come from married households whose parents are gambir farmers with income between Rp. 1,200,000.- up to Rp. 3,200,000.- every month, or an average of Rp. 2,200,000 per month per household per month. The average number of perpetrators is 4 people. It is assumed that at least the number of household members of the offender's family is 6 people consisting of 4 children and 2 parents with a poverty line of $\mathrm{Rp} 250,000$.- per head. Child marriages in the study location did not come from marital households categorized as poor. That each parent's household has a television and at least one motorbike supports the conclusion above. Thus, child marriage at the research location is not to solve household economic problems. Therefore, we need to look at other things.

Duration of school also found not an important cause. Indeed, a link was found between the length of time to pursue formal education and the age of first marriage. The level of education of parents when married is the same as education when a child is married, that is, graduating from elementary school, but it cannot be concluded that they are intertwined in a causal relationship. At the research location, quitting school at the elementary and junior high school level is a social condition that drives the perpetrators and their parents to the marriage of children. It was found that school stops at the junior secondary level due to marriage.

This study found the effect of weak parental control / social control on the continuation of child marriages at the study site. Parents are not fully able to "attend" in children's lives socially. This is a consequence of the livelihoods of residents. The main job of parents is gambir farmers. 
Parents usually go to the fields every morning and return home after late afternoon. Even when pressing (extracting gambir leaves) farmers spend more time in the fields, can 5-6 days a week just come back home. It is not uncommon for farmers' wives to join their husbands in the fields. This situation results in the daily behavior of children less able to be monitored by parents and unknown to parents. This provides an opportunity for children to carry out the activities they want, including activities related to sexuality. This requires us to look at another phenomenon in this society which is dating early age.

It was found at the study site that dating early age was considered a facilitator of child marriage. Children have started dating first when they were around the age of 14 (graduating from elementary school). Since the beginning of dating, the marriages of the children who have been studied intend to find a marriage partner. Girls try to maintain relationships with their boyfriend by meeting frequently. Girls are very worried about being abandoned by their girlfriends. This concern is reasonable, at the research site boys often struggle to change girlfriends. To keep a boyfriend to marriage, girls do as often as possible to meet a boyfriend somewhere in the nagari and travel outside the nagari. The ways they do to maintain that relationship lead them to child marriage. First, parents view their daughter who travels outside the village for a long time with a man is considered an escape attempt. There is an assumption that "a day" for their daughters to leave with their boyfriends is deemed to be no longer a virgin. Their parents sanction the acts of these girls by marrying them to the age of their children.

As an illustration, Ani (not her real name) is asked to stop her parents and cellphone were confiscated because her parents discovered that she often skipped school because she met her boyfriend (called courtship). After quitting school, Ani did not stop meeting her boyfriend because he was worried that he would be left. Through intensive contact using his cellphone, Ani and her boyfriend decided to go both to the city of Padang (this is called escaping). A week later Ani's parents managed to find them and finally decided to get married. Second, the high intensity of meeting girls with her boyfriend in places in the nagari and outside the nagari caused moral problems and norms customs norm among female parents bro. Parents solve the moral issues and customary norms by marrying off their children. The main problem that is solved by marrying off a child who is a child of age is the concern of a moral behavior and gossip of others. Child marriage is a parent's solution to moral problems and customary norms. This concern is reasonable, lately two pairs of children under the age of 15 have been caught having sex and a video containing a teenage girl from the village of Nagari who has been researched doing lewdness with young people from other villages.

Are there any unwanted effects caused by child marriage? It seems that child marriage does not cause a high TFR in the nagari studied because married girls delay their first pregnancy. This can also be interpreted as the social reproduction of the daughters' marriages at the research location, not contributing to population growth. However, reproduction of child marriages has an impact on public health. Medically, child marriage causes women to be prone to eclampsia when they are pregnant at the age of 18 years. The condition of preeclampsia can trigger eclampsia, a seizure condition due to preeclampsia which can lead to maternal death. In addition, pregnant women who are too young have the potential to give birth to babies with low birth weight (LBW) or malnourished babies. Therefore, the number of infant deaths with LBW in the Coastal Strait is recorded at 73 deaths or 9/1000 births in 2010 (report from the South Coastal Health Office, 2012). The maternal mortality rate (AKI) of the South Coastal District, below the AKI of the Mentawai Islands Regency, which is around 226 / 100,000 live births, can be concluded contributed by the amount of the marriage of girls. The study did not have data that would allow statistical analysis to find the relationship between child marriages and infant mortality with LBW and AKI, but the results of interviews with midwives stated that from their 
experience the incidence of maternal morbidity and mortality related to pregnancy under the age of 18 could be the basis for concluding that the mortality rate of infants with LBW and AKI in the South Coast is also contributed by the reproductive marriage of girls. Third, socially found child marriage places girls vulnerable to domestic violence (domestic violence). All female perpetrators of child marriages said they experienced physical violence from their husbands. Married women at the age of the child were stated to look old (far older than their age) by FGD participants whose participants from adolescents were unmarried.

\subsection{Limited Reproductive Health Knowledge}

Analysis of the results of the FGD and in-depth interviews with children and adolescents at the study site showed that adolescents did not have sufficient knowledge about reproductive health to be able to be responsible for their own reproductive organs. The marriage perpetrators of the girls studied said they used contraceptives to delay pregnancy. This shows that they are knowledgeable about how to control pregnancy as recommended by the government. However, their knowledge is not sufficient to protect themselves from the negative effects caused by the use of sexual organs. First, the reproductive health phrase is unknown. This shows that they have never followed the talks of health officials, health cadres, and reproductive health activists. These phrases are used by them to convey reproductive health messages. The FGD participants said that teachers in the school had alluded to human reproduction in religious subjects but they called it only "fleeting". Second, the act of maintaining the reproductive organs is interpreted as an act of orientation "moral ethics" that is maintaining lust, maintaining faith, and maintaining the good name of the family. Sexual intercourse is only known to cause pregnancy in women.

\section{Discussion}

\subsection{Understanding the social practices of child marriage, seen in the significance of discourse and symbols.}

The practice of child marriage in the nagari studied is an intergenerational phenomenon, there is a social reproduction of child marriage by a new generation or generation of children. The indication is that all parents of daughters who carried out the marriages of the children under study (15 cases) also had marriages at early childhood, that is, between the ages of 14-16 years for mothers and between 16-22 years for fathers. According to the informant, at that time, couples married early in the past (mentally) stronger, independent and mature, contrary to the condition of early marriage in the present era.

Economic reasons are not important causes of child marriage at this time, but the status of marriage is itself important. For female parent households, the marriage of girls raises the economic burden of their households, because their daughter-in-law is also an economic burden on the parents' household. Therefore, in Nagari Koto Nan Tigo Utara Surantih child marriage is not the solution to overcome the economic burden of the parents' household.

Dating children (early age) is normal and is left by the Nagari community. They interpret dating as self-evident "marks" favored by the opposite sex and for marriage. Girls try to keep their boyfriend to marry them. 
Parents see their daughters who travel outside the nagari for a long time with a man is considered an escape attempt. There is an assumption that "the only day" their daughter goes with her boyfriend is considered to be no longer a virgin.

\subsection{Understanding the social practices of child marriage, seen in aspects of dominance individual external mastery.}

It was found at the study site that dating early age was considered a facilitator of child marriage. Children have started dating first when they were around 14 years old (graduating from elementary school). Girls try to maintain relationships with their boyfriend by meeting frequently. Girls are very worried about being abandoned by their girlfriends. This concern is reasonable, at the research site boys often struggle to change girlfriends. To maintain a girlfriend until marriage, girls do as often as possible to meet a boyfriend somewhere in the nagari and travel outside the nagari. The means of electronic social media greatly help their affirmations for that.

Dating carried out by children includes sexual activities that often lead to pregnancy outside of marriage. Submission of "self" and "honor" is considered as proof of self-loyalty to the opposite sex (female to male).

Parents are not fully able to "attend" in children's lives socially. The consequences of local residents' livelihoods. The main job of parents is gambir farmers. Parents usually go to the fields every morning and return home after late afternoon. Even when pressing (extracting gambir leaves) farmers spend more time in the fields, can 5-6 days a week just come back home. It is not uncommon for farmers' wives to join their husbands in the fields.

School time was found not to be an important cause. Indeed, a link was found between the length of time to pursue formal education and the age of first marriage. The level of education of parents when married is the same as education when a child is married, that is, graduating from elementary school, but it cannot be concluded that they are intertwined in a causal relationship. At the research location, quitting school at the elementary and junior high school level is a social condition that drives the perpetrators and their parents to the marriage of children. It was found that school stops at the junior secondary level as a result of marriage (not marriage because of dropping out of school).

\subsection{Understanding the social practices of child marriage, seen in the aspects of normative (formal and non-formal) legitimacy structures.}

The Child Protection Mechanism Law No.23 of 2002, does not synergize with the Marriage Law No.1 of 1974. The concept of not being allowed to marry in Law No.23 of 2002 is children under the age of 18, while according to Law No.1 1974 states that for women not to be married aged <16 years, and <19 for men. Unless there is a parent's permission with an official letter, this is the door to manipulating the marriage permit via 'bribe' (age issue). This phenomenon will be increasingly difficult and complicated for the implementation program of maturing the age of marriage, when religious and customary factors are very permissive about it (opening a gap for individuals).

The high intensity of meeting girls with their girlfriends in places in the nagari and outside the nagari raises moral issues and customary norms among female parents. The main problem that is solved by marrying off a child who is a child of age is the concern of a moral behavior and gossip of others. 
Child marriage does not cause a high TFR in the nagari studied because girls who are married to contraceptive methods have delayed their first pregnancy. This can also be interpreted as the reproduction of the marriage of girls in the research locations that do not contribute to population growth, thus there is a reason to get married early without having to have children directly.

The act of guarding the reproductive organ is interpreted as an act oriented towards moral ethics, namely maintaining lust, maintaining faith, and maintaining the good name of the family. Sexual intercourse is only known to cause pregnancy in women.

\section{References}

[1] Adam Kuper \& Jessica Kuper, 2000. Ensiklopedi Ilmu Ilmu Sosial, PT. Raja Grafindo Persada, Jakarta.

[2] Amran, Rusli. 1985. Sumatra Barat, Plakat Panjang, Penerbit Sinar Harapan, Jakarta.

[3] Abdul Munim, DZ, 2002. Tanah Yang Dijanjikan:Studi Historis Antropologis Lahirnya Sebuah Desa di Jawa, Pustaka Tosemito, Jakarta

[4] Chatra, Emeraldy.1999. Adat Salingka Desa, Pusat Studi Pembangunan Dan Perubahan Sosial Budaya Unand, Padang.

[5] Chaedar, alwasilah A. 2003. Pokoknya Kualitatif, Pustaka Jaya, Bandung.

[6] Deddy, Mulyana, 2001. Metodologi Penelitian Kualitatif, Paradigma Baru Ilmu Komunikasi Dan Ilmu Sosial lainnya, Reamaja Rosdakarya, Bandung.

[7] Efi, Yandri, et al.2003. Nagari Dalam Perspektif Sejarah, Penerbit Lentera 21, Padang.

[8] Franz, Von Benda, Beckmann, 2000. Properti Dan Kesinambungan Sosial, Grasindo, Jakarta.

[9] Giddens, Anthony, 2003. Teori Strukturasi untuk Analisis Sosial, Pedati, Pasuruan.

[10] Graves, Elizabeth E. 1984. The Minangkabau Response To Dutch Colonial Rule In The Ninteenth Century, Cornel University Ithaca, New York.

[11] Indraddin.2016. Strategi dan Perubahan Sosial, Yogyakarta: Deepublish

[12] Keebet Von Benda-Beckmann.2000. Goyahnya Tangga Menuju Mufakat, Gramedia Widiasarana Indonesia, Jakarta.

[13] Lauer, Robert H 1993- Perspektif Tentang Perubahan Sosial, Penerbit Rineka Cipta, Jakarta.

[14] LKAAM, 2002. Adat Basandi Syarak, Syarak Basandi Kitabullah, Pedoman Hidup Bernagari, Sako Batuah, Padang.

[15] Mestika Zed; Alfan Miko dan Emeraldy Chatra.1992. Perubahan Sosial di Minangkabau Implikasi Kelembagaan dalam Pembangunan Sumatera Barat, Pusat Studi Pembangunan dan Perubahan Sosial Budaya Universitas Andalas, Padang.

[16] Mardjamni Martamin, dkk, 2002, Sejarah Perjuangan Minangkabau, Kerjasama Masyarakat Sejarawan Indonesia dengan Dinas Parawisata Seni dan Budaya Sumatera Barat.

[17] Navis, AA, 1984, Alam Takambang Jadi Guru, Adat Dan Kebudayaan Minangkabau, Grafiti Pers, Jakarta,

[18] Navis, AA, (Ed), 1983. Dialektika Minangkabau Dalam Kemelut Sosial dan Politik, Genta Singgalang Press, Padang.

[19] Poloma, Margaret M. 1984. Sosiologi Kontemporer, Yayasan Solidaritas Gajah Mada dan Rajawali, Jakarta.

[20] Peraturan Daerah Provinsi Sumatera Barat Nomor 9 tahun 2000. Tentang Ketentuan Pokok Pemerintahan Nagari.

[21] Tommy Firman. 1997. "Migrasi Antarpropinsi dan Pengembangan Wilayah di Indonesia ". Majalah Prisma No. 7 Tahun 1997, LP3ES, Jakarta.

[22] Usman Pelly dan Asih Menanti. 1994. Teori-Teori Sosial Budaya. Depdikbud RI, Jakarta.

[23] Warsito, Rukmadi dkk, 1984. Transmigrasi: Dari Tempat Awal Sampai Benturan Budaya di Tempat Pemukiman, CV. Rajawali, Jakarta. 
[24] Yeremias T. Kemban. 1997. "Studi Niat Berimigrasi di Tiga Kota; Determinan dan Intervensi", Majalah Prisma No. 7 Tahun 1997, LP3ES. Jakarta. 